\title{
Metabolism and Thermoregulation in Crosses between Wild and Random-bred Laboratory House Mice (Mus domesticus)
}

\section{Christopher S. Richardson*}

\section{Michael R. Dohm}

\section{Theodore Garland, Jr.}

Department of Zoology, University of Wisconsin, Madison, Wisconsin 53706

Accepted 2/18/94

\begin{abstract}
We conducted a "common garden" experiment to compare aspects of thermoregulation and metabolism in wild and random-bred laboratory bouse mice (Mus domesticus) and their reciprocal crosses. Analysis of covariance (ANCOVA) indicated that, after accounting for effects of body mass and other appropriate covariates (e.g., age), wild $(\mathrm{N}=12)$ and bybrid $(\mathrm{N}=25)$ mice together tended to have higher $(+9.7 \% ; \mathrm{P}=.0904)$ maximal nonshivering thermogenesis (max-NST) in response to norepinephrine injection than did lab mice $(\mathrm{N}=18)$. Wild $(-17.2 \% ; \mathrm{P}=.0941)$ and bybrid (wild dam: $-23.1 \% ; \mathrm{P}=.0001$; lab dam: $-11.2 \% ; \mathrm{P}=.0749$ ) mice also tended to have lower basal metabolic rates (BMRs) than did lab mice. As a consequence of these trends, wild and bybrid mice, analyzed together, bad significantly bigher $(+18.2 \% ; \mathrm{P}=.0263)$ regulatory NST (max-NST minus BMR) than did lab mice. Paralleling the differences in regulatory NST, wild and bybrid mice together bad significantly more $(+21.2 \% ; \mathrm{P}=$ .0129) interscapular brown adipose tissue than did lab mice. However, plasma thyroid bormone levels (triiodotbyronine $\left[T_{3}\right]$ and thyroxine $\left[T_{4}\right]$ ) showed no significant differences among groups, and, even for the traits that exbibited significant differences, the overlap of values for individual mice was substantial. Moreover, mean values for max-NST and BMR for all four groups fell well within the range of values reported in the literature for small mammals. We therefore concluded that random-bred laboratory mice are not necessarily "degenerate" with respect to their metabolic and thermoregulatory capacities. Finally, the two reciprocal cross groups differed in BMR $(\mathrm{P}=.0314)$, which thus indicated a maternal influence: wild-dam $\times$ lab-sire mice had significantly lower BMRs than did lab-dam $\times$ wild-sire mice.
\end{abstract}

* Present address and address for correspondence: Department of Biology, 5 Cummington St., Boston University, Boston, Massachusetts 02215 . 


\section{Introduction}

Laboratory strains of house mice (Mus domesticus) often serve as model systems in behavior, morphology, physiology, and quantitative genetics (Festing 1979; Foster, Small, and Fox 1981; Falconer 1989; Lyon and Searle 1989; Plomin, DeFries, and McClearn 1990; Gordon 1993). However, Mus has been used less often in physiological ecology or in evolutionary phys. iology (Berry 1981; Jakobson 1981; Lynch 1986, 1992, 1994; Barnett and Dickson 1989; Burggren and Bemis 1990; Tomasi and Horton 1992; Garland and Carter 1994). From the perspective of physiological ecology, questions arise as to the suitability of using laboratory Mus as models for making inferences about adaptation or other evolutionary processes in nature. Many researchers believe domestication results in "degeneracy," and that laboratory animals may be maladaptive forms unrepresentative of their wild counterparts (Barnett 1975; Smith 1978; Festing 1979; references in Boice 1981; Price 1984; Marek and Szacki 1988; Barnett and Dickson 1989; Bronson 1989; Geiser et al. 1990; Tomasi and Gleit 1992, p. 77). One way to address such concerns is to compare the physiological capacities (e.g., maximal nonshivering thermogenesis [max-NST]) of laboratory animals and their wild counterparts.

Domestication is a process through which animals become adapted to a captive environment by some combination of genetic changes occurring over generations and of environmentally induced developmental events reoccurring during each generation (Price 1984). The ancestors of most current laboratory Mus strains were originally removed from the wild almost 100 yr ago (Festing 1979; Berry 1981; Plomin et al. 1990; Atchley and Fitch 1991). Thus, about 300-400 generations of mice (with the assumption that there are three to four generations per year) have experienced the domestication process. Furthermore, much genetic variation (e.g., in allozymes for protein-coding loci) exists among strains of laboratory Mus and among populations of wild Mus (Selander 1970; Festing 1979; Berry 1981; Sage 1981; Atchley and Fitch 1991). Laboratory strains of Mus are also known to differ in many aspects of the metabolic or thermoregulatory phenotype, such as in mass of brown adipose tissue (BAT; references in Jakobson 1981; Thornhill and Halvorson 1992; references in Gordon 1993). Thus, genetically based differences in physiological traits between laboratory and wild mice are certainly possible.

A common garden design is necessary to determine if genetically based differences exist between laboratory and wild Mus (Garland and Adolph 1991). Such a design involves making measurements on offspring of wild and lab mice bred and raised under the same environmental conditions 
(e.g., in the laboratory). In addition, a comparison of hybrid mice with pure wild and/or laboratory mice (all bred and raised in the same environment) can elucidate the underlying nature of any genetic differences (e.g., the presence of genetic dominance). Finally, a comparison of the two types of hybrid offspring (wild dam $\times$ lab sire vs. lab dam $\times$ wild sire) indicates whether maternal (or possibly paternal) influences exist (Garland and Adolph 1991).

A primary focus of physiological ecology has been the study of energetics, and small mammals have been common subjects (Jansky 1973; Grodzinski and Wunder 1975; Lynch 1986, 1992, 1994). In small mammals, the allocation of energy among maintenance metabolism, growth and reproduction, and thermoregulation has been of particular interest (Wunder 1992). A mammal must first meet the energetic demands and costs of thermoregulation before energy can be expended on other functions (Wunder 1984; Tomasi and Horton 1992). When at rest within their thermoneutral zone (the range of ambient temperatures over which an animal's minimal energy expenditure is sufficient for maintaining normothermic body temperatures), mammals produce a minimal ("basal") amount of heat, but, when they are exposed to lower temperatures, additional sources of heat production are used. Locomotor or other activities produce additional heat but may compromise overall thermal conductance and may interfere with shivering (another major source of heat production; Bartholomew 1982).

Another additional source of heat production is nonshivering thermogenesis (NST), a thermogenic mechanism that liberates chemical energy through processes that do not involve muscular contractions (Jansky 1973; fig. 1). Two types of NST have been defined, basal and regulatory. Basal NST is the rate of metabolism of a resting, postabsorptive mammal in its thermoneutral zone, whereas regulatory NST is the additional heat production (not from muscle contractions) that occurs at ambient temperatures below the thermoneutral zone (Jansky 1973; Bartholomew 1982). Consistent with Jansky's terminology, we will refer to regulatory NST as NST, and basal NST as basal metabolic rate (BMR). A major source of regulatory NST in the mammalian body is BAT. About $60 \%-70 \%$ of NST induced by norepinephrine (NE) is attributable to BAT (Foster and Frydman 1978), although NST also occurs in the muscles and in the liver (Jansky 1973). Cold exposure in the laboratory (at least $2.5 \mathrm{~h} / \mathrm{d}$ ) induces the growth of BAT in house mice (Heldmaier 1975; Wunder 1981). Furthermore, an enhanced capacity for max-NST (basal + regulatory NST) has been reported for several rodent species after laboratory cold acclimation (Wunder 1992; Gordon 1993). The physiology and anatomy of BAT is discussed by Lindberg (1970) and by Trayhurn and Nicholls (1986). 


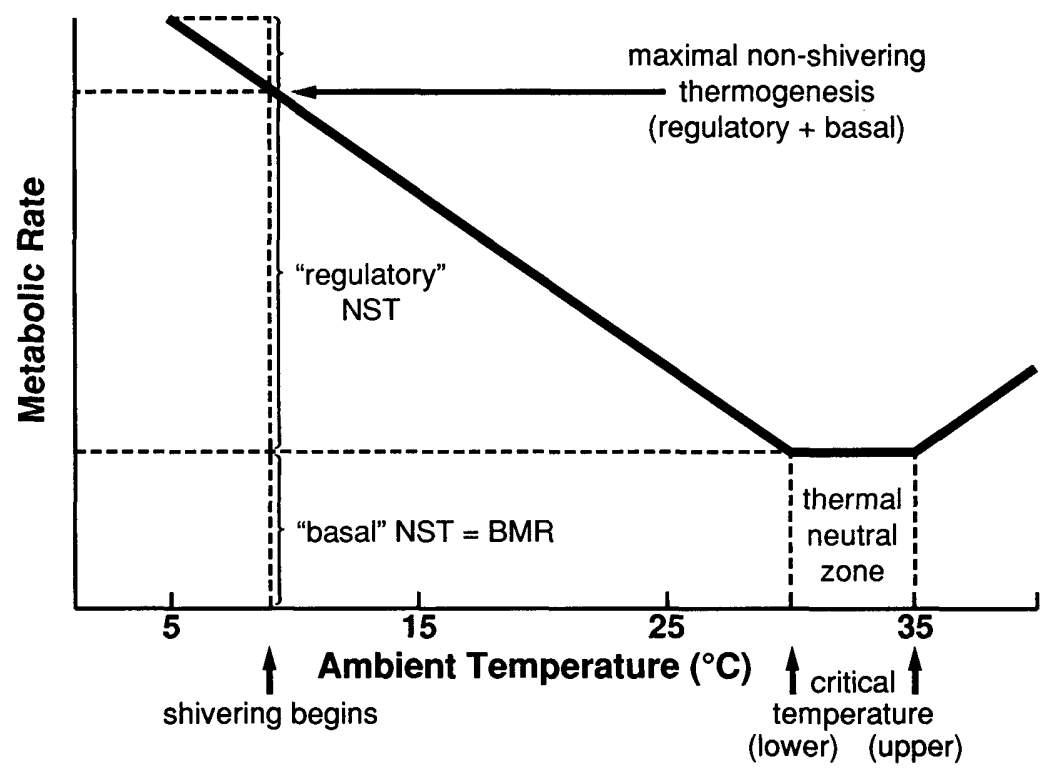

Fig. 1. Scheme of thermogenic mechanisms of small mammals during cold exposure (redrawn from Jansky 1973).

Only small eutherian (placental) mammals $(<10 \mathrm{~kg})$ and newborns of some larger eutherian species possess BAT-mediated NST (Heldmaier 1971; Trayhurn and Nicholls 1986; Hayward and Lisson 1992). As compared with large mammals, small mammals are particularly challenged by cold exposure, because they have higher mass-specific thermal conductances and relatively small amounts of insulation and cannot greatly increase insulation with fur or fat without impairing locomotion (Hart 1971; Webster 1974; Bartholomew 1982). Nonshivering thermogenesis enables small mammals to increase heat production rapidly during cold exposure (Wunder 1984, 1992). The ability for NST is generally considered to be an evolutionary adaptation, because it allows small mammals to remain normothermic while active in the cold (Webster 1974; Bartholomew 1982).

A complex array of subcellular, cellular, neural, and hormonal factors affect BMR (Denckla and Marcum 1973; Hulbert 1978, 1987; Bartholomew 1982). The thyroid hormones triiodothyronine $\left(T_{3}\right)$ and thyroxine $\left(T_{4}\right)$ are particularly important and can elevate organismal metabolic rate within 12 $\mathrm{h}$ (Hulbert 1978). In rodents, cold exposure may mildly increase the thyroid secretion rate of $\mathrm{T}_{3}$ and $\mathrm{T}_{4}$ (Withers and Hulbert 1988), and cold acclimation has often been reported to increase minimal metabolic rates (Mason 1974; Lynch et al. 1976; Jakobson 1981; Wunder 1992). Thyroid function may also correlate with interspecific differences in the metabolic rate in rodents 
(Yousef and Johnson 1975; but see Hulbert, Hinds, and MacMillen 1985, and Tomasi and Gleit 1992).

Laboratory house mice typically experience relatively constant ambient temperatures of about $20^{\circ}-24^{\circ} \mathrm{C}$, which is somewhat below thermoneutrality $\left(\sim 30^{\circ}-32^{\circ} \mathrm{C}\right.$ for house mice; Jakobson 1981$)$. Wild house mice probably experience temperatures within their thermoneutral zone while in nests, but, during foraging bouts in winter, they can experience ambient temperatures well below thermoneutrality (Jakobson 1981). The grain bins at the stables where the wild mice for the present study were caught are located in an unheated, drafty loft exposed to wind and precipitation. The presence of mouse droppings and the areas in the stables where mice were captured indicate that they are frequently exposed to cold, drafty conditions. For example, for Dane County Airport, about $17 \mathrm{~km}$ east of the study site, 10yr averages of minimum daily temperatures for December, January, and February are $-10.3^{\circ} \mathrm{C},-11.2^{\circ} \mathrm{C}$, and $-9.4^{\circ} \mathrm{C}$, respectively, with at least 24 $\mathrm{d}$ in each month with temperatures below $0^{\circ} \mathrm{C}$. Because wild mice experience periods of extreme cold exposure that laboratory mice do not, we expected the former to have higher capacities for NST (and more BAT). A clear prediction is possible for NST (and BAT mass), because studies have shown that the more severe the cold exposure (even if intermittent), the greater the BAT mass and the higher the NST (see, e.g., Mejsnar and Jansky 1971; Jansky 1973; Heldmaier 1975; Gordon 1993). However, because many factors (e.g., diet) in addition to cold exposure can influence BMR (and plasma thyroid hormone levels), we do not see a clear prediction of the $\mathrm{BMR}$ of wild mice relative to that of laboratory mice.

\section{Material and Methods}

\section{Animal Husbandry and Breeding Design}

We studied four lab-bred groups of house mice (Mus domesticus): wild $\times$ wild, wild dam $\times$ lab sire, lab dam $\times$ wild sire, and lab $\times$ lab. The wild parents were captured in Sherman live traps during March-July 1992 from a single population located at the University of Wisconsin-Madison's Hoofer's Horse Stables, in Middleton, Dane County, Wisconsin. We did not capture any lactating or pregnant females (no litters were born after capture). Lyme disease, caused by the spirochete Borrelia burgdorferi with the deer tick (Ixodes dammini) as the major vector, is prevalent in small mammals such as Peromyscus leucopus in the northwestern and west-central counties of Wisconsin, including Dane county. Although no I. dammini were found on house mice in a recent survey of ectoparasites of small mammals of 
Wisconsin, house mice could, nonetheless, be infected (D. I. Kissel, unpublished data). Concern over human health and the health of our wild breeder mice led us to check for $B$. burgdorferi infection in the wild mice. Sera of 10 males captured at the stables, and later paired for breeding, tested negative (E. C. Burgess, School of Veterinarian Medicine, University of Wisconsin-Madison) for antibodies to B. burgdorferi by both the indirect immunofluorescent antibody assay and by Western blot analysis (Burgess et al. 1986; Burgess 1992).

The laboratory parents were from the random-bred HSD/ICR strain of mice (hereafter referred to as ICR) obtained from Harlan Sprague Dawley, Indianapolis, Indiana, where they were maintained at approximately $73^{\circ}$ $\pm 2^{\circ} \mathrm{F}\left(22^{\circ}-24^{\circ} \mathrm{C}\right)$. Most lab sires and all lab dams arrived on July 22,1992 ; some lab sires had arrived on May 13, 1992. All lab parents were 40-45 d old on arrival. The physiology, morphology, and life history of this strain have been extensively studied (Robeson, Eisen, and Leatherwood 1981; Riska, Atchley, and Rutledge 1984; Eisen 1986; Hayes, Garland, and Dohm 1992). The random-bred and inbred lines used to create the ICR strain were all pure Mus domesticus, as are all wild Mus in North America (Berry 1981; Sage 1981; Ferris et al. 1983; Tucker et al. 1992).

All mice were housed in standard clear plastic cages $(27 \mathrm{~cm}$ long, $17 \mathrm{~cm}$ wide, $12.5 \mathrm{~cm}$ deep) with metal or wire tops and wood shavings as bedding. Room temperature was maintained at approximately $22^{\circ} \mathrm{C}$ and photoperiod was 12L:12D, centered at 1300 hours (CST). Water was available ad lib. Food (Harlan Teklad Laboratory Rodent Diet) was available ad lib., except before measurements of NST and BMR were taken. All lab males and females were housed in same-sex groups of four to five. Wild males were housed singly. All wild females were housed in groups of three in constant darkness from July 9-30, 1992, and were disturbed as little as possible. The 3 wk of darkness was suggested by C. B. Lynch (personal communication) as a way to enhance breeding success in wild mice.

Mice were paired on July 30, 1992. Wild and lab males were assigned randomly to each cross group; wild females were paired randomly with wild and lab males, and lab females were assigned arbitrarily to wild and lab males. All pairs were kept in the same room and in constant darkness and were disturbed as little as possible. All cages had tin cans $(12.6-\mathrm{cm}$ long, 7.8-cm diameter) for nesting. We checked for litters once each day (18001900 hours) starting on August 16, 1992. When litters were found, the male was removed. Only seven of 17 wild pairs and 13 of 17 wild-dam $\times$ lab-sire pairs produced litters, as compared to 12 of 13 wild-sire $\times$ lab-dam pairs and 19 of 20 lab pairs $\left(\chi^{2}\right.$ Pearson value $=17.22$, df $\left.=3, P=.00064\right)$. After the litters were 1 wk old, which was just before the pups' eyes opened, 
photoperiod was changed back to $12 \mathrm{D}: 12 \mathrm{~L}$, centered at 1300 hours (CST), with relocation of the cages to an adjacent room. When the litters were 21 $\mathrm{d}$ old, offspring were weaned from the mother, weighed, toe-clipped, and housed in groups of three to four by sex and cross type.

To ensure statistical independence of our data points, only one female offspring per family was chosen (randomly) for measurement. However, because of the relatively low number of litters produced by wild $\times$ wild pairings, a second female offspring was also chosen randomly from five wild $\times$ wild families, which thus yielded a total $N$ of 56 . In a similar way, Lynch (1986, 1992) and Plomin and Manosevitz (1974) used more than one offspring per family for their common garden comparisons of wild house mice populations, as did Scheck (1982a) for his common garden comparison of two populations of cotton rats (Sigmodon bispidus). We also repeated all statistical analyses, omitting the five extra individuals, and found that all $P$ values for dummy variables and covariates were very similar to the $P$ values from analyses in which all 12 wild individuals were used; conclusions as to statistical significance were unchanged. We therefore report only the results from analyses in which all 12 wild $X$ wild mice were used.

We studied only one sex to eliminate possible sex-related variation, which could reduce our power to detect group differences. We studied females because four of the litters contained no males. For logistical reasons, not all individuals could be measured at exactly the same age, but we attempted to reduce age variation within and among groups, while making sure the age spread overlapped in all four groups. Age at first measurement ranged from $33 \mathrm{~d}$ to $51 \mathrm{~d}$, and age at testing was therefore used as a covariate in statistical analyses for all traits (see below). Measurements were taken September 20 through October 22, and all mice were killed by cervical dislocation and dissected by December 11, 1992.

\section{Measurement of NST}

Mice were fasted at least $12 \mathrm{~h}$ before measurement of NST. Fasting reduces or eliminates the effects of digestion and of metabolism of recently ingested food on overall metabolic rate (Blaxter 1989). Metabolic measures were assayed during the photophase between 0800 and 1900 hours. An index of max-NST (basal + regulatory NST) is determined by measuring oxygen consumption after an injection of NE (Bruck 1970). Because an injection of NE may inhibit the release of endogenous NE, an optimal dosage is required to compensate for the inhibitory effect (Bockler, Steinlechner, and Heldmaier 1982). From measurements of the NE response in hybrid mice that had been either sham-injected or injected at one of three doses $(.003$ 
$\mathrm{mg} \mathrm{NE} / \mathrm{g}$ body mass, $.004 \mathrm{mg} \mathrm{NE} / \mathrm{g}$ body mass, or $.005 \mathrm{mg} \mathrm{NE} / \mathrm{g}$ body mass), we determined that a dose of $.004 \mathrm{mg} \mathrm{NE} / \mathrm{g}$ body mass in a volume of $.012 \mathrm{~mL} / \mathrm{g}$ body mass elicited a maximal metabolic response. To avoid contamination and degradation of $\mathrm{NE}$, a fresh NE solution $(.33 \mathrm{mg} \mathrm{NE} / \mathrm{mL}$; [-]-norepinephrine bitartrate salt [Sigma]; lactated Ringer's injection, USP [Baxter]) was prepared no more than $2 \mathrm{~d}$ prior to injection.

To minimize handling, each mouse was quickly encouraged to enter, head first, a clear acrylic tube with a rubber stopper at one end. A bottle brush was used to push the mouse toward the stoppered end. For the subcutaneous injection, interscapular skin was pinched up through a rectangular opening cut into the tube near the stoppered end. Immediately after injection, the mouse was pushed out of the tube into the metabolic chamber. We observed each mouse throughout the trial, and its activity level was recorded every $30 \mathrm{~s}$ as inactive (0), active (1), or grooming (2) (reversing the scores for active and grooming resulted in lower explanatory power by the summed activity covariate; see below). Individual mice were monitored for 55 min after injection, with baseline (ambient) oxygen concentration recorded $5 \mathrm{~min}$ before and $5 \mathrm{~min}$ after each trial.

Nonshivering thermogenesis trials were conducted at $20^{\circ} \mathrm{C}$ to minimize the risk of hyperthermia; metabolic chamber temperature was recorded with a thermocouple every $5 \mathrm{~min}$ for all 55 trials and averaged $20.0^{\circ} \pm .05^{\circ} \mathrm{C}$ $( \pm \mathrm{SE})$. A negative pressure, open-circuit respirometry system was used. A downstream pump drew room air through a Drierite column, through a glass metabolic chamber $(525 \mathrm{~mL})$, into a Drierite/Ascarite II/Drierite column (for the removal of water and $\mathrm{CO}_{2}$ ), and, finally, through a thermal mass-flow controller (Sierra Instruments, Monterey, Calif., Side $=$ Track Model 844). Flow rates were 450,500 , or $600 \mathrm{~mL} \mathrm{~min}^{-1}$ standard temperature and pressure, dry (STPD), depending on animal size. Air venting from the pump was then subsampled at $150-200 \mathrm{~mL} \mathrm{~min}^{-1}$ STPD, with a second downstream pump pulling the sample through a Drierite/Ascarite II/Drierite column, a mass-flow controller, and an Applied Electrochemistry S-3A/II oxygen analyzer (Amtek, Pittsburgh, Pa.). The oxygen analyzer was interfaced to an analog-to-digital converter and microcomputer. Oxygen concentration was measured (as millivolt readings) 20 times/s with a 1 -s average recorded. Maximal NST was estimated as the highest rate of oxygen consumption $\left(\dot{\mathrm{V}}_{2}\right)$, averaged over a 2 -min interval, with the first $10 \mathrm{~min}$ and the last $10 \mathrm{~min}$ of the $55-\mathrm{min}$ trial excluded. The first and last $10 \mathrm{~min}$ were excluded because the peak response to NE is known to occur approximately 10-20 min after injection and does not last more than 5-10 min (Heldmaier 1971; Feist and Rosenmann 1976; personal observation). We calculated $\dot{\mathrm{V}}_{2}$ by means of equation (4a) of Withers (1977). Because equation (4a) assumes 
steady state conditions (i.e., constant $\dot{\mathrm{V}}_{2}$ throughout the measuring interval, or a change in $\dot{\mathrm{V}}_{2}$ taking longer than the system washout time), or a respirometry system with little volume (e.g., open-circuit respirometry system with mask), instantaneous values for the highest $\dot{\mathrm{V}}_{2}$ were also determined by adjusting for chamber washout (Bartholomew, Vleck, and Vleck 1981; Frappell, Blevin, and Baudinette 1989). Our system's effective volume was $458 \mathrm{~mL}$. The data analysis program corrected for baseline drift (as did the BMR analysis program) using linear regression and then calculated both steady state and instantaneous $\dot{\mathrm{V}}_{2}$ values.

\section{Measurement of BMR}

After NST trials, mice were given approximately $24 \mathrm{~h}$ of rest (with food and water) then were fasted again for at least $12 \mathrm{~h}$ before measurement of BMR the following morning. For BMR, oxygen consumption was measured at $32^{\circ} \mathrm{C}$ in a positive-pressure, open-circuit respirometry system, as described previously (Hayes et al. 1992). Seven mice, each in a separate chamber, plus an empty control chamber, were each monitored consecutively for 7.5 min of each hour for 7-8 h (ANCOVA indicated that BMR did not differ significantly among channels). Each metabolic chamber received dry air at

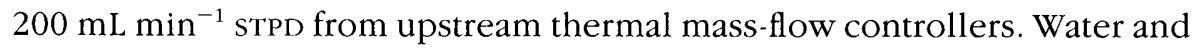
$\mathrm{CO}_{2}$ were removed from the chambers' excurrent air with Drierite and Ascarite II, respectively. Excurrent air from each chamber was subsampled at

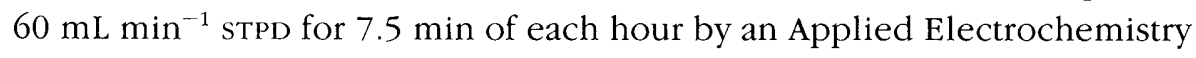
$\mathrm{S}-3 \mathrm{~A} / \mathrm{II}$ oxygen analyzer interfaced to an analog-to-digital converter and microcomputer; the data acquisition program (interpreted BASIC) measured and recorded oxygen concentration (as millivolt readings) once per 5-s sample interval. Excurrent air from each chamber was diverted to the oxygen analyzer by an automated system with solenoid valves under programmed control. We calculated $\dot{\mathrm{V}}_{2}$ for the last $5 \mathrm{~min}$ of the 7.5 -min sampling interval by means of equation (4) of Hill (1972). The flow rate and chamber volume we used ensured that the previous chamber's excurrent air had cleared the respirometry system downstream of the metabolism chamber before the start of the 5-min measurement interval. The data analysis program corrected for drift in the control channel (baseline) by means of linear regression to calculate predicted baseline values throughout the course of the hour. The analysis program calculated the lowest and second lowest 5-min intervals of oxygen consumption of the day for each mouse.

\section{Other Measurements}

After measurement of BMR, four other physiological and/or behavioral performance measures were recorded for the mice: 2 consecutive days of the 
maximal rate of oxygen consumption $\left(\dot{\mathrm{V}}_{\mathrm{O}_{2 \max }}\right), 2$ consecutive days of sprint speed, 2 consecutive days of swimming endurance, and 1 wk of voluntary wheel running (Dohm, Richardson, and Garland, in press). Mice were then killed and dissected at 86-92 d of age. Immediately prior to sacrifice by cervical dislocation, blood was taken with microhematocrit capillary tubes from the suborbital sinus and centrifuged for $6.5 \mathrm{~min}$. Plasma samples were frozen on dry ice and then stored at $-80^{\circ} \mathrm{C}$. Analyses of the plasma concentration of the thyroid hormones $\mathrm{T}_{3}$ and $\mathrm{T}_{4}$ were later performed by the Radionucleotide Laboratory, School of Veterinary Medicine, University of Wisconsin-Madison.

Immediately after sacrifice, tail length was measured with a ruler to the nearest $.5 \mathrm{~mm}$. The tail may function as a thermoregulatory organ during heat stress (Jakobson 1981). The interscapular brown adipose tissue (IBAT) was then removed and frozen. The mass of IBAT is often used as an indicator of regulatory NST capacity (Lynch 1973; Heldmaier 1975; Wunder 1981; Lynch 1986, 1992), because IBAT represents approximately 50\% of total BAT and can be conveniently removed intact. Later, the two lobes of IBAT were defrosted in deionized water and were carefully cleaned of surrounding white adipose tissue. The IBAT was then gently blotted dry, and wet mass was recorded.

\section{Statistical Analyses}

All statistical analyses were performed by means of SPSS/PC+ version 5.0 (Norusis 1992). Multiple regression analysis, with appropriate covariates (e.g., body mass, age, time of day) and the cross group coded as 0-1 dummy variables (equivalent to ANCOVA), was used for all group comparisons. Some variables were transformed to improve normality and/or homoscedasticity. Preliminary analyses indicated little or no significant among-group differences for the relationships between the dependent variables and the covariates (i.e., no heterogeneity of slopes was found). Furthermore, we see no obvious reason to expect that the relationship between covariates, such as body mass, and dependent variables, such as BMR, would differ between wild and lab mice. Independent variables were considered to be significant at $P<.05$.

Several comparisons were performed for each trait. First, the two hybrid groups were compared to test for maternal (or paternal) effects. If hybrids showed no significant differences, which was the case for all traits except BMR, they were then pooled for subsequent comparisons. Second, the wild, pooled hybrid, and lab groups were compared in a three-group comparison. This comparison was considered the most reliable test for possible wild- 
lab differences, because the body mass of the hybrids overlapped the body mass of both the wild and lab mice. The wild and lab groups were not compared alone, because the comparison is problematic; body mass is highly correlated with most of the traits we measured, and the two groups showed little overlap in body mass (wild mice are smaller; see table 1 and figs. 25). Thus, the dummy variable for the lab versus wild comparison alone is highly correlated with one of the covariates, body mass, which leads to problems of multicollinearity (Slinker and Glantz 1985). For all comparisons involving the lab group, lab mice were coded 0 for all dummy variables.

Because the sample size of the pooled hybrid group was twice as large as the sample size of the wild group, several tests showed significant differences between hybrid and lab mice but not between wild and lab mice, even though the magnitude of the difference was similar. We therefore paid close attention to the magnitude of the estimated difference (after accounting for all covariates) between each group and the lab group (as judged by the partial regression coefficients for the dummy variables). When the pooled hybrid and wild mice differed from the lab by a similar magnitude, we compared them statistically. If the pooled hybrid and wild mice did not differ significantly, they were then pooled together and compared with the lab mice.

Body mass and age at measurement were used as covariates for all traits. In preliminary analyses, we also used litter size at weaning as a covariate, but this was never statistically significant, so we excluded litter size from the final analyses. All $P$ values for dummy variables and covariates from analyses with litter size were qualitatively similar to the $P$ values from analyses without litter size. For the thyroid hormones and IBAT, the time of day when sacrifice occurred and the $z$-transformed time of day squared were used as covariates (the $z$-transformation reduces the correlation between time of day and time of day squared). Using both time of day and time of day squared allows for any nonlinear association between time and the dependent variable. For IBAT, preliminary analyses indicated that the number of days between the NST trial (and NE injection) and the removal of IBAT had no significant relationship with IBAT mass, so this covariate was omitted from the final analyses. For BMR, the total time fasted (total time from when food was removed to when the lowest $\dot{\mathrm{V}}_{2}$ occurred) was also used as a covariate (see Hayes et al. 1992).

For max-NST, the total time fasted (total time from when food was re. moved to when highest $\dot{\mathrm{V}}_{2}$ occurred) was used as a covariate. The time of day of the midinterval of highest $\dot{\mathrm{V}}_{2}$ and the $z$-transformed time of day squared were also included as covariates. For each NST trial, a summed activity score was computed for intervals ranging from 1 to $10 \mathrm{~min}$, at 30-s 


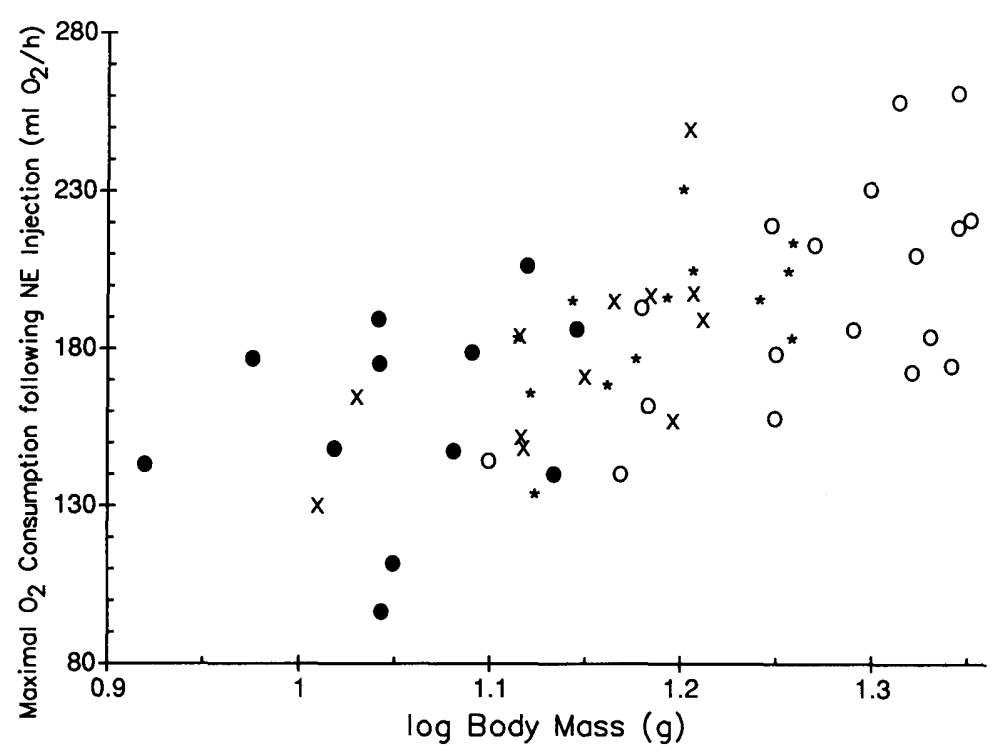

Fig. 2. Maximal oxygen consumption (instantaneous-corrected $\dot{\mathrm{VO}}_{2}$ values) after an NE injection (max-NST) versus $\log _{10}$ body mass. Filled circles, wild $\times$ wild; stars, wild dam $\times$ lab sire; $X$, lab dam $\times$ wild sire; open circles, lab $\times$ lab.

increments, preceding the midinterval time of the max-NST (highest $\dot{\mathrm{VO}}_{2}$ averaged over $2 \mathrm{~min}$ ). We performed analyses with all 19 different summed activity scores, including all other necessary covariates, and determined that the 4-min activity score for instantaneous-corrected $\mathrm{V}_{2}$ values and the 5min activity score for steady state $\dot{\mathrm{V}}_{2}$ values explained the greatest amount of the variance (highest partial $r^{2}$ ) in max-NST. We therefore used the 4 min or 5-min scores in all analyses. We also found no significant amonggroup differences for the 4 -min or the 5 -min activity scores. As in previous studies, regulatory NST was computed by subtracting BMR from max-NST (see, e.g., Jansky 1973; Lacy and Lynch 1979; Haim et al. 1984; Wunder 1992). All comparisons were then performed with the same covariates used in the max-NST comparisons, except that an average of body mass from both measurement days was used, and the total time fasted for BMR was also included.

\section{Results}

Descriptive statistics for all traits measured (including the adjusted means from the ANCOVA) in wild, hybrid, and laboratory Mus domesticus are pre- 


\begin{tabular}{|c|c|c|c|c|c|c|c|c|}
\hline Trait & $\bar{X} \pm \mathrm{SE}$ & & $\begin{array}{l}\text { Adjusted } \\
\text { Mean }^{\mathrm{a}}\end{array}$ & $N$ & Minimum & Maximum & $\begin{array}{l}\text { Mean } \\
\text { Body } \\
\text { Mass } \\
(\mathrm{g})\end{array}$ & $\begin{array}{l}\text { Mea } \\
\text { Age } \\
\text { (d) }\end{array}$ \\
\hline \multicolumn{9}{|l|}{$\begin{array}{l}\text { Maximal nonshivering } \\
\text { thermogenesis }\left(\mathrm{mL} \mathrm{O}_{2} \cdot \mathrm{h}^{-1}\right):^{\mathrm{b}}\end{array}$} \\
\hline Wild $\ldots \ldots \ldots \ldots \ldots \ldots$ & 158.6 & \pm 9.50 & 198.8 & 12 & 96.7 & 206.7 & 11.5 & 45.0 \\
\hline Hybrids $\ldots \ldots \ldots \ldots \ldots \ldots$ & 183.6 & \pm 5.59 & 185.6 & 25 & 130.3 & 249.9 & 14.8 & 37.9 \\
\hline Lab $\ldots \ldots \ldots \ldots \ldots \ldots$ & 196.1 & \pm 8.38 & 166.8 & 18 & 140.4 & 261.5 & 19.0 & 38.7 \\
\hline \multicolumn{9}{|l|}{ Basal metabolic rate $\left(\mathrm{mL} \mathrm{O}_{2} \cdot \mathrm{h}^{-1}\right)$ : } \\
\hline$\ldots \ldots \ldots \ldots \ldots \ldots$ & 21.4 & \pm 1.03 & 26.7 & 12 & 15.5 & 26.2 & 11.2 & 47.5 \\
\hline Hybrid, wild dam $\ldots \ldots \ldots \ldots$ & 25.5 & \pm 1.41 & 24.8 & 13 & 15.8 & 34.3 & 14.6 & 41.3 \\
\hline Hybrid, lab dam ........... & 28.1 & \pm 1.34 & 28.7 & 12 & 20.2 & 39.2 & 14.3 & 38.4 \\
\hline Lab $\ldots \ldots \ldots \ldots \ldots \ldots \ldots$ & 38.4 & \pm 1.27 & 32.3 & 19 & 28.8 & 51.2 & 18.0 & 40.3 \\
\hline
\end{tabular}


Regulatory nonshivering

thermogenesis $\left(\mathrm{mL} \mathrm{O}_{2} \cdot \mathrm{h}^{-1}\right):^{\mathrm{b}}$

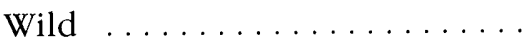

Hybrids .................

$137.2 \pm 9.77 \quad 163.0$

$12 \quad 72.1$

182.3

11.3

46.3

Lab

$156.8 \pm 5.66$

160.6

25

105.8

221.2

14.6

38.9

Interscapular brown adipose tissue

$157.9 \pm 8.45$

135.3

$18 \quad 98.2$

221.2

18.6

39.7

( $\mathrm{g}$ wet mass):

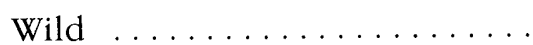

\begin{tabular}{rrrrcccc}
$.072 \pm .0023$ & .087 & 12 & .061 & .083 & 14.5 & 86.9 \\
$.083 \pm .0032$ & .084 & 23 & .049 & .110 & 20.9 & 87.8 \\
$.082 \pm .0033$ & .068 & 16 & .060 & .108 & 27.5 & 89.2 \\
$.086 \pm .0052$ & $\ldots$ & 17 & .060 & .153 & 27.8 & 89.2 \\
$1.04 \pm .039$ & $\ldots$ & 52 & .58 & 2.08 & 21.7 & 88.1 \\
$43.7 \pm 1.81$ & $\ldots$ & 44 & 20.0 & 75.0 & 21.4 & 88.0 \\
\hline
\end{tabular}

${ }^{a}$ Adjusted means are from ANCOVAs corresponding to tables 2-5. All covariates were used for computations, regardless of their statistical significance, and adjustments were made to grand mean values for all individuals in the analysis. Where dependent variables were log transformed prior to analyses, values represent back transformations.

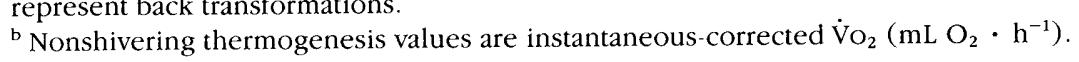


sented in table 1. After the appropriate covariates were accounted for, the only trait showing a statistically significant difference between the two hybrid groups was BMR (table 1). Hybrid mice from wild dams had significantly lower BMRs than did hybrid mice from lab dams $\left(\mathrm{F}_{1,20}=5.36, P=.0314\right)$.

With the exception of BMR, wild mice did not differ significantly from either group of hybrid mice, so the following presentation of results emphasizes comparisons of (1) lab mice with wild and with pooled hybrids (i.e., a three-group comparison; see tables 2, 3, and 4) or (2) lab mice with pooled wild plus hybrid mice (i.e., a two-group comparison).

Figure 2 shows the expected positive relationship between maximal oxygen consumption after NE injection (max-NST) and $\log _{10}$ body mass. Both wild $(+19.1 \% ; P=.1058)$ and hybrid $(+11.2 \% ; P=.0649)$ mice tended to have higher max-NST than did lab mice (table 2 ). Pooled wild plus hybrid mice also tended to have higher max-NST than did lab mice $\left(+9.7 \% ; \mathrm{F}_{1,47}\right.$ $=2.99, P=.0904)$. Figure 3 indicates the positive relationship between BMR and body mass on a $\log _{10}-\log _{10}$ scale. As compared with lab mice, both wild $(-17.2 \% ; P=.0941)$ and hybrid mice (wild dam: $-23.1 \%$; $P=.0001$; lab dam: $-11.2 \% ; P=.0749)$ tended to have lower BMRs (table 5).

Wild $(+20.5 \% ; P=.2290)$ and hybrid $(+18.7 \% ; P=.0324)$ mice exhibited higher regulatory NST (max-NST minus BMR) than did lab mice (table 3 ). As shown in figure 4 , the pooled wild plus hybrid mice had significantly higher regulatory NST than did the lab mice $\left(+18.2 \% ; \mathrm{F}_{1,46}=5.27, P=.0263\right)$.

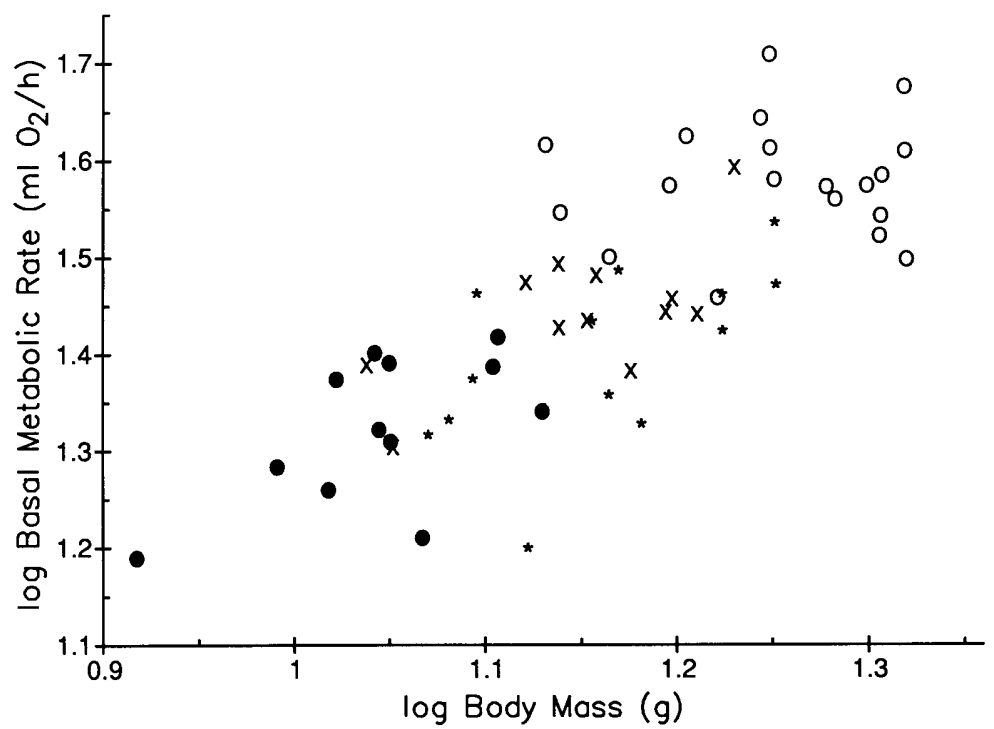

Fig. 3. $\log _{10}$ BMR versus $\log _{10}$ body mass. Symbols are as in figure 2. 
All comparisons of max-NST or of regulatory NST using steady state $\dot{\mathrm{V}}_{2}$ values gave qualitatively similar results, and so they are not reported here. The correlation of instantaneous-corrected and steady state values was .958 $(N=55)$, with the instantaneous value averaging $13.0 \% \pm .73 \%( \pm \mathrm{SE} ; N$ $=54$ ) higher (this mean difference excludes one outlier datum, in which the instantaneous value was $53.2 \%$ higher).

Both wild $(+28.1 \% ; P=.1053)$ and hybrid $(+23.7 \% ; P=.0179)$ mice had more IBAT than did lab mice (table 4 ). (One lab mouse was judged a statistical outlier, because it had much more IBAT than the rest [.153 $\mathrm{g}$ IBAT of $32.98 \mathrm{~g}$ body mass; cf. fig. 5]. This individual was excluded from analyses because its inclusion violated statistical assumptions even when various transformations were applied.) As shown in figure 5, the pooled wild plus hybrid mice had significantly more IBAT than did the lab mice $(+21.2 \%$; $\left.\mathrm{F}_{1,45}=6.70, P=.0129\right)$. Tail length was highly correlated with body mass, but showed no significant differences among groups (all $P>.19$; ANCOVA table not shown). Plasma thyroid hormone levels showed no significant differences among groups (all $P>.27$; ANCOVA table is not shown; pooled mean values are reported in table 1$)$.

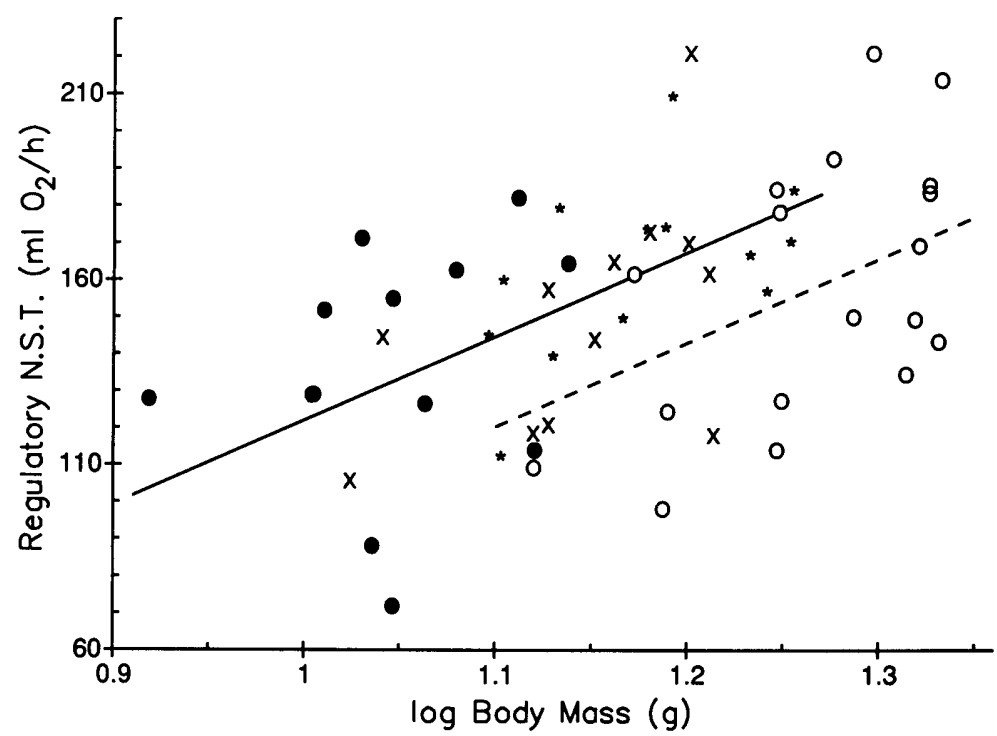

Fig. 4. Regulatory NST (instantaneous-corrected max-NST minus BMR) versus $\log _{10}$ body mass. Regression lines represent pooled within-groups slope ( $\mathrm{b}=227.0 ; \mathrm{P}=.0001)$ from ANCOVA with body mass as the only covariate: the solid line represents pooled wild plus bybrid mice and the dashed line represents lab mice. Symbols are as in figure 2. 


\section{Discussion}

The domestication of house mice has involved both evolutionary (genetic) and physiological adaptation to laboratory conditions different from those experienced in nature (Berry 1981; Jakobson 1981; Price 1984; Barnett and Dickson 1989; Bronson 1989). By using a common garden experimental design (thus controlling for possible physiological adaptation [i.e., acclimation]) we found that, after accounting for effects of body mass and other appropriate covariates, the wild and hybrid mice together had significantly higher $(+18.2 \%)$ regulatory NST (max-NST minus BMR) and significantly more $(+21.2 \%)$ IBAT than did the random-bred laboratory mice we had studied (figs. 4, 5). However, we found no significant differences in plasma thyroid hormone levels.

Although the wild and hybrid mice in our study differed from the lab mice for regulatory NST and for IBAT mass by similar magnitudes, and although the differences between hybrid and lab mice were statistically significant (tables 3,4 ), the differences between wild and lab mice were not statistically significant. This discrepancy is attributable to the approximately twofold higher sample size of the pooled hybrid group as compared

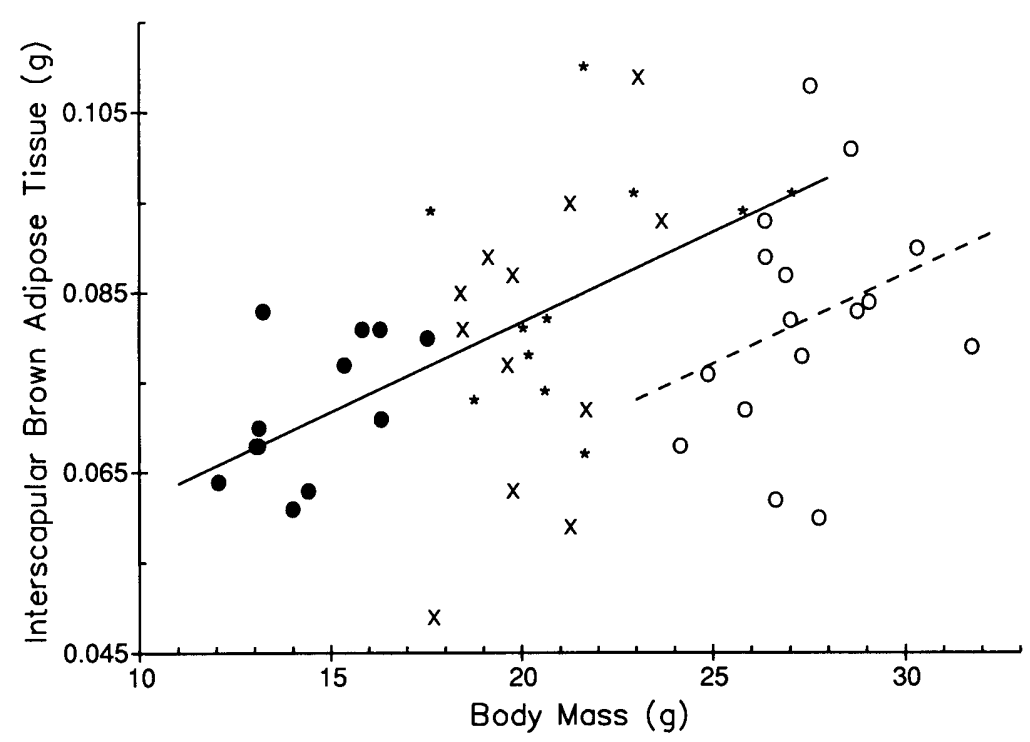

Fig. 5. Wet mass of IBAT versus body mass (minus one outlier; see Results). The regression lines represent pooled within-groups slope (b $=.0020 ; \mathrm{P}=.0004)$ from ANCOVA with body mass as the only covariate: the solid line represents pooled wild plus bybrid mice and the dashed line represents lab mice. Symbols are as in figure 2. 
to the wild group. (The number of individuals measured and the number of breeding pairs in our study is typical of other small rodent studies [see, e.g., Smith 1972; Plomin and Manosevitz 1974; Rosenmann and Morrison 1974; Connor 1975; Scheck 1982a, 1982b; Haim et al. 1984; Lynch 1986; Millar and Threadgill 1987; Geiser et al. 1990].) Because (1) wild and hybrid mice show similar magnitudes of difference from the lab mice (and wild and hybrid mice do not show significant differences, see figs. 4 and 5) and (2) the difference between hybrid and lab mice is statistically significant, we conclude that the magnitude of the difference between wild mice and their lab counterparts is also significant.

The marginal statistical significance of the differences between wild and lab mice (tables 2-5) and the extent of overlap between groups in the distributions of individual values (figs. 2-5) suggest that thermoregulatory function has not "degenerated" greatly in the random-bred ICR strain. Furthermore, a comparison of our values for the ICR strain with values reported in the literature (fig. 6; table 6) demonstrates that both max-NST and BMR (and, hence, regulatory NST) for the ICR strain fall well within the range exhibited by various wild small mammals. Thus, random-bred ICR house mice are not necessarily unrepresentative of wild small mammals with respect to their thermoregulatory capacities.

Some other studies of small mammals have also reported thermoregulatory differences related to domestication. For example, Geiser et al. (1990) found

TABLE 2

ANCOVA for max-NST: lab versus wild and versus pooled bybrids

\begin{tabular}{|c|c|c|c|}
\hline Source of Variation & $\mathrm{df}$ & $F$ & $P$ \\
\hline Group (wild) & 1 & 2.722 & .1058 \\
\hline Group (hybrids) & 1 & 3.576 & .0649 \\
\hline $\log _{10}$ body mass $\ldots$. & 1 & 21.378 & $<.0001$ \\
\hline Age $\ldots \ldots \ldots \ldots \ldots$ & 1 & 1.741 & .1936 \\
\hline Fast length ... & 1 & .049 & .8258 \\
\hline Time . . . . . . . . & 1 & .328 & .5695 \\
\hline $\operatorname{Time}^{2}$ & 1 & .012 & .9119 \\
\hline Activity score & 1 & 11.051 & .0017 \\
\hline Model . . . . . . . . . . & 8 & 7.886 & $<.0001$ \\
\hline Residual & 46 & $\ldots$ & $\ldots$ \\
\hline
\end{tabular}


that, unlike field-fresh mountain pygmy possums, lab-bred individuals never fattened or entered torpor. Barnett et al. (1975) showed that 12 generations of cold exposure had different effects on wild and lab mice with respect to the amount of fat stored in adipose tissue. However, the $20 \%$ higher summit metabolism of field-fresh wild mice as compared with albino lab mice reported by Rosenmann and Morrison (1974) is reduced or disappears when proper allowance is made for the negative allometry of mass-specific metabolic rate (see, e.g., fig. 6). None of the foregoing studies was of a true common garden design. In a common garden experiment, Foley et al. (1971) found that neonatal feral hogs were more cold resistant (because of greater heat production and extra pelage) than were neonatal domestic hogs.

Population differences for such metabolic and thermoregulatory traits as NST have also been reported previously in wild rodents, including Mus (see, e.g., Haim et al. 1984; reviews in Jakobson 1981, MacMillen and Garland 1989, and Garland and Adolph 1991). These differences may reflect evolutionary adaptation to different thermal environments. For example, with field-fresh animals, differences in IBAT mass among island populations of wild house mice (reported and analyzed as $\mathrm{mg} / \mathrm{g}$ body mass) showed a negative correlation with meteorological temperature (mean annual or mean monthly island temperature; Berry and Jakobson 1975; Berry, Bonner, and

\section{TABLE 3}

ANCOVA for regulatory NST: lab versus wild and versus pooled bybrids

Source of Variation

df

F

P

Group (wild)

1.487

.2290

Group (hybrids)

4.875

.0324

$\log _{10}$ body mass

9.690

.0032

Age

Basal metabolic rate fast length .....

Nonshivering thermogenesis fast

length

Time

Time $^{2}$

Activity score

Model

Residual
1.265 .2667

1

1.793

$1 \quad 2.850$

.0983

1

.002

.9674

1

7.276

.0098

9

4.244

.0005 
Peters 1979; Jakobson 1981). In a similar way, a $60^{\circ}$ north latitude Russian population of Mus showed higher cold-induced metabolic rates than did a $45^{\circ}$ north latitude population (Ladygina 1952, cited in Hart 1971). Finally, a high-altitude Mus population exhibited a higher summit metabolism (maximum cold-induced metabolic rate) than did a low-altitude population (Rosenmann and Morrison 1974; their use of per gram values is not a problem in this comparison, because these mice were approximately the same size). (In rodents, differences in summit metabolism primarily reflect differences in max-NST, because cold acclimation stimulates NST capacity, not shivering capacity [Jansky 1973; Jakobson 1981; Wunder 1984].) Populations can also diverge because of genetic drift (see, e.g., Smith [1985] on lab mice), but drift will not tend to produce population differences that are correlated with environmental (selective) variation.

The studies of population differences listed in the previous paragraph were not of a common garden design. In such cases, observed differences can be the result of environmental effects, not just genetic differences (Garland and Adolph 1991). The high plasticity in response to seasonal changes (Hart 1971; Jakobson 1981; Feist 1984; Merritt 1984; Wunder 1992), the effects of early cold exposure on development (Lynch et al. 1976), and the possibility of maternal effects for such traits as NST, BAT, BMR, and thyroid hormone levels, all suggest that much of the population variation for these traits may not be genetically based (see Burggren and Bemis 1990, p. 203). On the other hand, a number of studies indicate that genetically based population differences in physiological traits can evolve quite rapidly (ref-

TABLE 4

ANCOVA for mass of IBAT: lab versus wild and versus pooled bybrids

\begin{tabular}{|c|c|c|c|}
\hline Source of Variation & $\mathrm{df}$ & $F$ & $P$ \\
\hline Group (wild) & 1 & 2.735 & .1053 \\
\hline Group (hybrids) ..... & 1 & 6.053 & .0179 \\
\hline Body mass . . . . . . . . . & 1 & 4.030 & .0509 \\
\hline Age $\ldots \ldots \ldots \ldots \ldots$ & 1 & 3.300 & .0761 \\
\hline Time at sacrifice $\ldots .$. & 1 & 3.454 & .0698 \\
\hline Time $^{2} \ldots \ldots \ldots \ldots$ & 1 & .741 & .3939 \\
\hline Model ........... & 6 & 3.630 & .0052 \\
\hline Residual $\ldots \ldots \ldots$ & 44 & $\ldots$ & $\ldots$ \\
\hline
\end{tabular}


erences in Garland and Adolph 1991). For example, a common garden study of five wild North American Mus domesticus populations from a north-south cline along the eastern U.S. coast demonstrated significant population differences in lipid-free IBAT mass (Lynch 1986, 1992, 1994) and in max-NST (B. Elder, W. Puchalski, and C. B. Lynch, personal communication), although not in the expected (adaptive) clinal direction. In any case, whether physiological differences among wild populations generally reflect nongenetic, physiological adaptation or genetic, evolutionary adaptation is unclear.

In the present study, hybrids tended to resemble their wild parents for BMR, regulatory NST, and amount of IBAT. When hybrid individuals resemble one or the other parent's phenotype, directional dominance is interpreted to be present at some or all of the loci affecting the trait (i.e., nonadditive genetic interactions within loci). In addition to reducing or exhausting additive genetic variance for a polygenic trait, directional selection should increase the number of dominant alleles in the direction of increasing fitness (Fisher 1958; Bruell 1964; Falconer 1989). Therefore, the presence of directional dominance can be interpreted as suggesting that past selection has acted to favor extreme values of the phenotype in a particular direction. According to this line of reasoning, our results would suggest that the wild mice we studied have experienced directional selection for low BMR, high regulatory NST, and large amounts of IBAT. This interpretation is consistent with the idea that they have faced selection for enhanced metabolic efficiency (e.g., low BMR) and/or high thermoregulatory abilities. Indeed, Lynch (1994) suggests that strong prior selection has oc-

TABLE 5

ANCOVA for BMR: lab versus wild and versus bybrid mice

\begin{tabular}{|c|c|c|c|}
\hline Source of Variation & df & $F$ & $P$ \\
\hline Group (wild) & 1 & 2.914 & .0941 \\
\hline Group (hybrid, wild dam) $\ldots$. & 1 & 17.490 & .0001 \\
\hline Group (hybrid, lab dam) & 1 & 3.312 & .0749 \\
\hline $\log _{10}$ body mass $\ldots \ldots \ldots \ldots$ & 1 & 14.612 & .0004 \\
\hline Age ... & 1 & 1.600 & .2119 \\
\hline Fast length .. & 1 & 12.657 & .0008 \\
\hline Model & 6 & 29.420 & $<.0001$ \\
\hline$\ldots \ldots \ldots$ & 49 & . & . . \\
\hline
\end{tabular}


curred on metabolic traits in all small mammals. On the other hand, lab strains may have experienced relaxed selection for metabolic efficiency (food is always available ad lib.) and for thermoregulatory abilities (intense cold never occurs; see Lacy and Lynch 1979, p. 750; Price 1984, p. 17). Also, as noted below, the ICR strain was once selected for large litters, which may have led to an elevation in BMR (but see Hayes et al. 1992 and the references therein).

Lynch $(1986,1992,1994)$ and colleagues have also investigated the genetic architecture of thermoregulatory traits such as IBAT. In a diallel cross among the five wild populations (Lynch 1994) and in two triple test-cross analyses of Lynch's Maine and Florida populations (B. Elder, personal communication), only nonadditive genetic effects were detected for IBAT mass. In this case, however, no clear directional dominance was found among the populations (Lynch 1994).

Maternal effects would be indicated by differences between the two reciprocal hybrid groups (wild dam vs. lab dam). The maternal environment is a potentially important factor in the development of physiological traits. For example, Cowley (1991) used embryo transplant experiments to demonstrate maternal influences on organ and fat pad masses in mice. In a similar way, growth rate and reproductive performance (e.g., litter size) in Mus are strongly affected by maternal influences, especially during cold

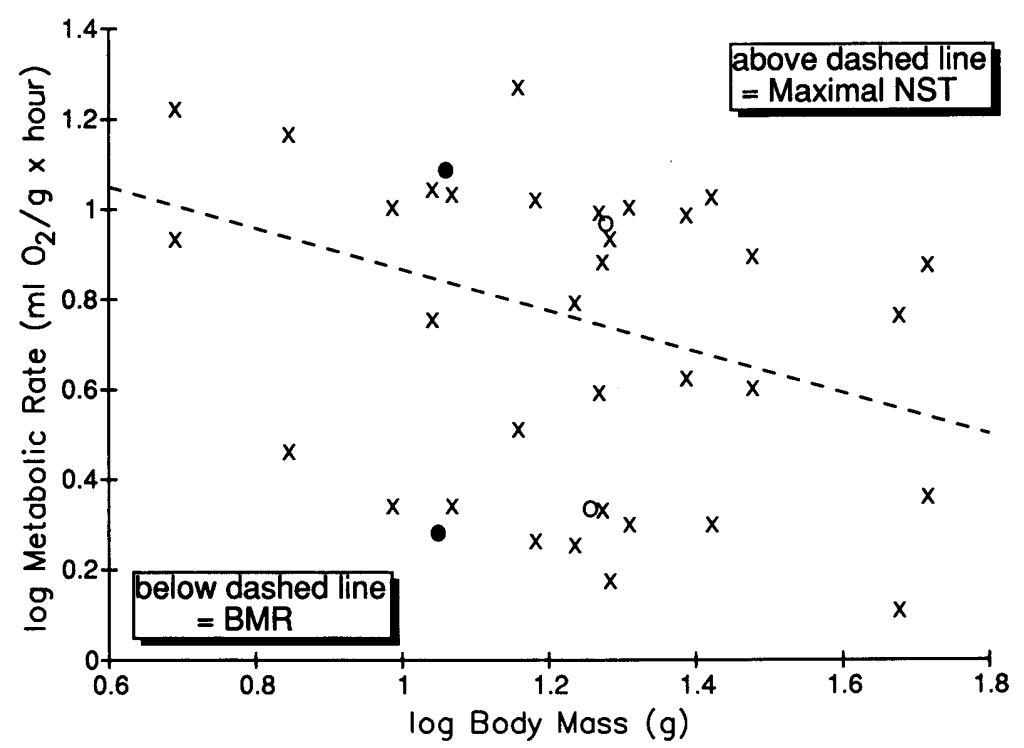

Fig. 6. Comparison of metabolic rates of other species of small mammals (X; table 6) with wild (filled circles) and random-bred laboratory (open circles) mice measured in this study. 
TABLE 6

Maximal metabolic response to NE (max-NST), resting metabolic rate (RMR), and body mass of small mammals as reported in the literature

\begin{tabular}{|c|c|c|c|c|c|}
\hline Species & $\begin{array}{l}\text { NE Dose and Route } \\
\text { of Administration }^{a}\end{array}$ & $\begin{array}{l}\max -\mathrm{NST}^{\mathrm{b}} \\
\left(\mathrm{mL} \mathrm{O} \mathrm{g}^{-1} \mathrm{~h}^{-1}\right)\end{array}$ & $\begin{array}{l}\mathrm{RMR}^{\mathrm{c}} \\
\left(\mathrm{mL} \mathrm{O} \mathrm{g}^{-1} \mathrm{~h}^{-1}\right)\end{array}$ & $\begin{array}{l}\text { Mass } \\
(\mathrm{g})\end{array}$ & Reference \\
\hline Mus domesticus . ........ & $4 \mathrm{mg} / \mathrm{kg}, \mathrm{sc}$ & 9.32 & 2.17 & 18.50 & This study \\
\hline Mus domesticus . ....... & $.5 \mathrm{mg} / \mathrm{kg}, \mathrm{sc}$ & 7.87 & 4.00 & 30.00 & Mejsnar and Jansky $1971^{\mathrm{d}}$ \\
\hline Mus domesticus . . . & $4 \mathrm{mg} / \mathrm{kg}, \mathrm{sc}$ & 12.27 & 1.92 & 11.32 & This study \\
\hline Mus domesticus . ........ & $4 \mathrm{mg} / \mathrm{kg}, \mathrm{im}$ & 7.65 & 2.15 & 18.75 & Jakobson 1978 \\
\hline Dicrostonyx groenlandicus & See belowe & 7.53 & 2.30 & 52.00 & Maier and Feist 1991 \\
\hline Microtus ochrogaster . . . . & $1.35 \mathrm{mg} / \mathrm{kg}, \mathrm{sc}$ & 5.80 & 1.29 & 47.55 & Wunder 1984, 1992 \\
\hline Clethrionomys rutilus .... & $3 \mathrm{mg} / \mathrm{kg}, \mathrm{sc}$ & 18.70 & 3.25 & 14.40 & $\begin{array}{l}\text { Feist and Rosenmann } \\
1976\end{array}$ \\
\hline Phodopus sungorus & $.8 \mathrm{mg} / \mathrm{kg}, \mathrm{sc}$ & 10.65 & 2.00 & 26.40 & Bockler et al. 1982 \\
\hline Peromyscus leucopus & See below ${ }^{f}$ & 10.10 & 2.00 & 20.40 & Zegers and Merritt 1988 \\
\hline Peromyscus maniculatus & See below ${ }^{f}$ & 10.50 & 1.84 & 15.20 & Zegers and Merritt 1988 \\
\hline Crocidura viaria ......... & $.1 \mathrm{mg} / \mathrm{kg}$, ip & 8.60 & 1.50 & 19.20 & Sparti 1992 \\
\hline
\end{tabular}




\begin{tabular}{|c|c|c|c|c|c|}
\hline Crocidura jouvenetae .... & $.1 \mathrm{mg} / \mathrm{kg}, \mathrm{ip}$ & 10.10 & 2.20 & 9.70 & Sparti 1992 \\
\hline Crocidura poensis & $.1 \mathrm{mg} / \mathrm{kg}$, ip & 6.20 & 1.80 & 17.20 & Sparti 1992 \\
\hline Crocidura suaveolens & $.1 \mathrm{mg} / \mathrm{kg}$, ip & 14.70 & 2.90 & 7.00 & Sparti 1992 \\
\hline Crocidura russula & $.1 \mathrm{mg} / \mathrm{kg}$, ip & 10.80 & 2.20 & 11.70 & Sparti 1992 \\
\hline Blarina brevicauda ..... & Dose not given, im & 9.83 & 3.92 & 18.57 & Merritt 1986 \\
\hline Sorex coronatus & $.1 \mathrm{mg} / \mathrm{kg}$, ip & 11.10 & 5.70 & 11.00 & Sparti 1992 \\
\hline Sorex minutus. & $.1 \mathrm{mg} / \mathrm{kg}, \mathrm{ip}$ & 16.70 & 8.60 & 4.90 & Sparti 1992 \\
\hline Myotis myotis & $.8 \mathrm{mg} / \mathrm{kg}, \mathrm{im}$ & 9.71 & 4.22 & 24.39 & Mejsnar and Jansky 1970 \\
\hline
\end{tabular}

Note. See figure 6.

${ }^{a}$ All doses are given as mg of NE per kg of body mass. Route of administration: sc, subcutaneously; im, intramuscularly; ip, intraperitoneally.

${ }^{\mathrm{b}}$ All max-NST values are the highest reported in a given study for nonanesthetized animals and are not instantaneous-corrected (values for this study are included, which are, therefore, different from those in table 1).

${ }^{\mathrm{c}}$ All RMR values are the lowest reported RMRs in a given study (nonactive and in the thermoneutral zone) (for Microtus ochrogaster, values for mass, RMR, and NE dose are taken from Wunder [1984]). In most cases the authors do not state whether the animals were fasted, although in some cases the animals were not fasted (see, e.g., Zegers and Merritt 1988).

${ }^{d}$ Values are for warm-acclimated lab mice (kept at $28^{\circ} \mathrm{C}$ ).

${ }^{\mathrm{e}}$ Dose $(\mathrm{mg} \mathrm{NE} / \mathrm{kg})=2.36$ (body mass) $^{-.4}$; subcutaneous injection.

${ }^{\mathrm{f}}$ Dose $\left.(\mathrm{mg} \mathrm{NE} / \mathrm{kg})=[6.6 \text { (body mass })^{-.458}\right] / 2$; intramuscular injection. 
exposure (Barnett and Dickson 1987, 1989). The only indication of a maternal effect in the traits studied herein was that hybrid offspring from wild dams had lower BMR than did hybrid offspring from lab dams.

In general, the lab mice we studied had higher BMRs than did the wild or hybrid mice (see table 5 and fig. 3). Reproductive variables have been hypothesized to correlate with BMR, and a recent comparative study of mammals found a possibly significant positive correlation between litter size and BMR, after effects of body mass and phylogeny were statistically controlled for (Harvey, Pagel, and Rees 1991). On the other hand, a previous study of individual variation in ICR mice (Hayes et al. 1992) found an insignificant positive correlation of $.134(N=78)$. The ICR strain was intentionally selected for large litters ( $>12$ pups) and for $100 \%$ weaning record from approximately 1948 into the mid-1960s (Hauschka and Mirand 1973). Therefore, ICR mice hold the record for litter size among domestic house mice ( $N=32$, with 26 pups being successfully weaned [Hauschka and Mirand $1973]$ ), and they routinely wean all of their pups and readily accept crossfostering of pups. In our study, mean litter sizes at weaning were 5.29 (range =3-8) for wild pairs, 5.08 (3-7) for wild-dam $\times$ lab-sire pairs, 10.25 (812) for wild-sire $\times$ lab-dam pairs, and 11.16 (8-14) for lab pairs (see also Hayes et al. 1992). Thus, ICR dams clearly produce larger litters than do wild dams, but it is unclear if this difference is related to BMR in any functional way, if it is a simple function of the difference in body size (see figs. 2-6 and Hayes et al. 1992), or if it is a function of some other difference between wild and ICR mice.

An important concern for any common garden study is whether those individuals that actually produce offspring are representative of their population. With respect to wild individuals brought into captivity, several sources of bias are possible. First, age and social status may affect which individuals are actually trapped and, therefore, which are sampled from the wild (see, e.g., references in Connor 1975; Barnett and Dickson 1989). In the present study, several trapping periods occurred over approximately 5 mo, so this potential bias should have been relatively small. Second, a relatively low success rate ( $50 \%$ or less) at producing litters when first brought into the laboratory is typical of wild rodents (see, e.g., Plomin and Manosevitz 1974; references in Connor 1975; Price 1984; Millar and Threadgill 1987; references in Bronson 1989; C. B. Lynch, personal communication). In the present study, for example, only seven of 17 wild $\times$ wild pairings produced litters, as compared with 19 of 20 lab pairings. Thus, selection may have occurred. In any case, Garland and Adolph (1991, p. 198) concluded that, "in many cases, studying lab-reared offspring of field-collected adults is the best compromise," and we followed their advice. 
Connor (1975) evaluated the effect of "natural selection in a laboratory habitat" by comparing over several generations a population of randombred, wild house mice raised in laboratory cages with a population of random-bred, wild house mice raised in a "naturalistic" environment. The naturalistic environment allowed for social conditions typical of wild house mice: opportunity to avoid aggressive conspecifics, space for territories and home ranges, opportunity for sexual interaction with more than one mate, and opportunity for agonistic encounters with same-sex conspecifics. After 10 generations, Connor (1975) found no genetically based behavioral differences (e.g., resistance to capture when released ["escapability"], avoidance of novel foods in familiar environments, agonistic behaviors between conspecifics [fighting, escaping, investigating]) between the wild mice born and reared in laboratory cages and the wild mice born and raised in the naturalistic environment. Connor (1975) concluded that no evidence exists to "support . . . the notion that natural selection in the laboratory induces striking and rapid behavioral alterations in newly domesticated populations," which is a conclusion also supported by Smith (1985). Moreover, although Millar and Threadgill (1987) found that some reproductive and developmental traits changed when they domesticated Peromyscus maniculatus over 11 generations, they and others (references in Millar and Threadgill 1987) generally found no major changes in reproductive and developmental patterns between wild and either short- or long-term domesticated Peromyscus stocks.

In summary, we found that random-bred laboratory ICR mice had significantly lower mass-corrected regulatory NST and mass of IBAT than did wild house mice from a Wisconsin population. Moreover, the lab mice were much larger in absolute body size (see figures and Dohm et al. [in press]). At $21 \mathrm{~d}$ of age, for example, mean body masses (g) were 9.2 for wild mice, 10.4 for hybrids from wild dams, 10.3 for hybrids from lab dams, and 11.1 for lab mice. On the other hand, our lab and wild mice did not differ in relative tail length or thyroid hormone levels, and the average difference in regulatory NST and in IBAT (both about 20\%) was not large. Whether such differences and/or similarities are a general feature of comparisons between laboratory strains and wild Mus domesticus populations is unclear. Both laboratory strains and wild populations of house mice show considerable variation in body size and in a variety of physiological traits (Festing 1979; Berry 1981; Jakobson 1981; Barnett and Dickson 1989; Gordon 1993). Because of such wide variation, no single strain or population may adequately represent either lab or wild forms. Caution should therefore be used when choosing lab strains as models for the study of wild populations or vice versa (see also Price 1984). 


\section{Acknowledgments}

We are grateful to D. D. Feist and J. P. Hayes for technical advice, P. S. Reynolds for assistance in capturing wild mice, C. Hannan for assistance with care of the study animals, and S. C. Richardson for general assistance. This project was supported by a Karl Entemann fellowship to M.R.D., grants from the National Science Foundation (BSR-9157268 [Presidential Young Investigator Award] and BNS-9111185) to T.G., by the University of Wisconsin Graduate School, and by equipment donations from Lafayette Instrument Company and San Diego Instruments.

\section{Literature Cited}

ATChley, W. R., and W. M. Fitch. 1991. Gene trees and the origins of inbred strains of mice. Science 254:554-558.

BarnetT, S. A. 1975. The rat: a study in behavior. $2 d$ ed. University of Chicago Press, Chicago. 318 pp.

BARnETT, S. A., and R. G. Dickson. 1987. Hybrids show parental influence in the adaptation of wild house mice to cold. Genet. Res. 50:199-204.

- 1989. Wild mice in the cold: some findings on adaptation. Biol. Rev. 64: 317-340.

Barnett, S. A., K. M. H. Munro, J. L. Smart, and R. C. Stoddart. 1975. House mice bred for many generations in two environments. J. Zool. Lond. 177:153-169.

Bartholomew, G. A. 1982. Body temperature and energy metabolism. Pages 333406 in M. S. Gordon, ed. Animal physiology: principles and adaptations. 4th ed. Macmillan, New York.

Bartholomew, G. A., D. Vleck, and C. M. VleCK. 1981. Instantaneous measurements of oxygen consumption during pre-flight warm-up and post-flight warm-up in sphingid and saturniid moths. J. Exp. Biol. 90:17-32.

BERRY, R. J. 1981. Town mouse, country mouse: adaptation and adaptability in Mus domesticus (M. musculus domesticus). Mammal Rev. 11:91-136.

Berry, R. J., W. N. Bonner, and J. Peters. 1979. Natural selection in house mice (Mus musculus) from South Georgia (South Atlantic Ocean). J. Zool. Lond. 189:385398.

BERRY, R. J., and M. E. JAKOBSON. 1975. Adaptation and adaptability in wild-living house mice (Mus musculus). J. Zool. Lond. 176:391-402.

Blaxter, K. 1989. Energy metabolism in animals and man. Cambridge University Press, Cambridge. 336 pp.

Bockler, H., S. Steinlechner, and G. Heldmaier. 1982. Complete cold substitution of noradrenaline-induced thermogenesis in the Djungarian hamster, Phodopus sungorus. Experientia 38:261-262.

BorCE, R. 1981. Behavioral comparability of wild and domesticated rats. Behav. Genet. 11:545-553.

Bronson, F. H. 1989. Mammalian reproductive biology. University of Chicago Press, Chicago. 325 pp. 
BRUCK, K. 1970. Nonshivering thermogenesis and brown adipose tissue in relation to age, and their integration in the thermoregulatory system. Pages 117-154 in O LINDBERG, ed. Brown adipose tissue. Elsevier, New York.

BRUELl, J. H. 1964. Inheritance of behavioral and physiological characters of mice and the problem of heterosis. Am. Zool. 4:125-138.

Burgess, E. C. 1992. Experimentally induced infection of cats with Borrelia burgdorferi. Am. J. Vet. Res. 53:1507-1571.

Burgess, E. C., T. E. Amundson, J. P. Davis, R. A. Kaslow, and R. Edelman. 1986. Experimental inoculation of Peromyscus spp. with Borrelia burgdorferi: evidence of contact transmission. Am. J. Trop. Med. Hyg. 35:355-359.

BurgGren, W. W., and W. E. Bemis. 1990. Studying physiological evolution: paradigms and pitfalls. Pages 191-228 in M. H. NITECKI, ed. Evolutionary innovations. University of Chicago Press, Chicago.

ConNor, J. L. 1975. Genetic mechanisms controlling the domestication of a wild house mouse population (Mus musculus L.). J. Comp. Physiol. Psychol. 89:118130.

Cowley, D. E. 1991. Genetic prenatal maternal effects on organ size in mice and their potential contribution to evolution. J. Evol. Biol. 3:363-381.

Denckla, W. D., and E. Marcum. 1973. Minimal $\mathrm{O}_{2}$ consumption as an index of thyroid status: standardization of method. Endocrinology 93:61-73.

Dohm, M. R., C. S. Richardson, and T. GARLAND, Jr. In press. Exercise physiology of wild and random-bred laboratory house mice and their reciprocal hybrids. Am. J. Physiol.

EISEN, E. J. 1986. Maturing patterns of organ weights in mice selected for rapid postweaning gain. Theor. Appl. Genet. 73:148-157.

FALCONER, D. S. 1989. Introduction to quantitative genetics. 3d ed. Longman, Wiley, New York. 438 pp.

FEIST, D. D. 1984. Metabolic and thermogenic adjustments in winter acclimatization of subarctic Alaskan red-backed voles. Pages 131-137 in J. F. MERritT, ed. Winter ecology of small mammals. Carnegie Museum of Natural History, Pittsburgh.

FEIST, D. D., and M. Rosenmann. 1976. Norepinephrine thermogenesis in seasonally acclimatized and cold acclimated red-backed voles in Alaska. Can. J. Physiol. Pharmacol. 54:146-153.

Ferris, S. D., R. D. Sage, E. M. Prager, U. Ritte, and A. C. Wilson. 1983. Mitochondrial DNA evolution in mice. Genetics 105:681-721.

FEsting, M. F. W. 1979. Inbred strains in biomedical research. Oxford University Press, New York. 483 pp.

FISHER, R. A. 1958. The genetical theory of natural selection. 2d ed. Dover, New York. 291 pp.

Foley, C. W., R. W. Seerley, W. J. Hansen, and S. E. Curtis. 1971. Thermoregulatory responses to cold environment by neonatal wild and domestic pigs. J. Anim. Sci. 32:926-929.

Foster, D. O., and M. L. Frydman. 1978. Nonshivering thermogenesis of the rat. II. Measurements of blood flow with microspheres point to brown adipose tissue as the dominant site of the calorigenesis induced by noradrenaline. Can. J. Physiol. Pharmacol. 56:110-122.

Foster, H. L., J. D. Smal., and J. G. Fox. 1981. The mouse in biomedical research. Vol. 1. History, genetics, and wild mice. Academic Press, New York. 306 pp. 
Frappell, P. B., H. A. Blevin, and R. V. BaudinetTe. 1989. Understanding respirometry chambers: what goes in must come out. J. Theor. Biol. 138:479-494.

Garland, T., JR., and S. C. AdolPh. 1991. Physiological differentiation of vertebrate populations. Annu. Rev. Ecol. Syst. 22:193-228.

Garland, T., Jr., and P. A. Carter. 1994. Evolutionary physiology. Annu. Rev. Physiol. 56:579-621.

Geiser, F., H. S. Sink, B. Stahl, I. M. Mansergh, and L. S. Broome. 1990. Differences in the physiological response to cold in wild and laboratory-bred mountain pygmy possums, Burramys parvus (Marsupialia). Aust. Wildl. Res. 17:535-539.

Gordon, C. J. 1993. Temperature regulation in laboratory rodents. Cambridge University Press, New York. 276 pp.

GrodzINSKI, W., and B. A. WUNDER. 1975. Ecological energetics of small mammals. Pages 173-204 in F. B. Golley, K. Petrusewicz, and L. RyszKowski, eds. Small mammals: their productivity and population dynamics. Cambridge University Press, London. $451 \mathrm{pp}$.

Haim, A., G. Heth, Z. Avnon, and E. Nevo. 1984. Adaptive physiological variation in nonshivering thermogenesis and its significance in speciation. J. Comp. Physiol. 154B:145-147.

HarT, J. S. 1971. Rodents. Pages 1-149 in G. C. Whitlow, ed. Comparative physiology of thermoregulation. Vol. 2. Mammals. Academic Press, New York.

Harvey, P. H., M. D. Pagel, and J. A. Rees. 1991. Mammalian metabolism and life histories. Am. Nat. 137:556-566.

Hauschka, T. S., and E. A. Mirand. 1973. The "breeder: HA(ICR)" Swiss mouse, a multipurpose stock selected for fecundity. Pages 319-331 in G. P. Murphy, D. Pressman, and E. A. Mirand, eds. Perspectives in cancer research and treatment. Riss, New York.

HAYES, J. P., T. GARLAND, JR., and M. R. DOHM. 1992. Individual variation in metabolism and reproduction of Mus: are energetics and life history linked? Funct. Ecol. 6:514.

HAYWARD, J. S., and P. A. Lisson. 1992. Evolution of brown fat: its absence in marsupials and monotremes. Can. J. Zool. 70:171-179.

Heldmaier, G. 1971. Nonshivering thermogenesis and body size in mammals. J. Comp. Physiol. 73:222-248.

-1975. The effect of short daily cold exposures on development of brown adipose tissue in mice. J. Comp. Physiol. 98:161-168.

HiLl, R. W. 1972. Determination of oxygen consumption by use of the paramagnetic oxygen analyzer. J. Appl. Physiol. 33:261-263.

HulberT, A. J. 1978. The thyroid hormones: a thesis concerning their action. J. Theor. Biol. 73:81-100.

- 1987. Thyroid hormones, membranes and the evolution of endothermy. Pages 305-319 in H. McLennan, J. R. Ledsome, C. H. S. McIntosh, and D. R. Jones, eds. Advances in physiological research. Plenum, New York.

Hulbert, A. J., D. S. Hinds, and R. E. MacMillen. 1985. Minimal metabolism, summit metabolism and plasma thyroxine in rodents from different environments. Comp. Biochem. Physiol. 81A:687-693.

JAKOBSON, M. E. 1978. Winter acclimatization and survival of wild house mice. J. Zool. Lond. 185:93-104. 
1981. Physiological adaptability: the response of the house mouse to variations in the environment. Symp. Zool. Soc. Lond. 47:301-335.

JANSKY, L. 1973. Non-shivering thermogenesis and its thermoregulatory significance. Biol. Rev. 48:85-132.

LACY, R. C., and C. B. LYNCH. 1979. Quantitative genetic analysis of temperature regulation in Mus musculus. I. Partitioning of variance. Genetics 91:743-753.

LindBerg, O. 1970. Brown adipose tissue. Elsevier, New York. 337 pp.

LYNCH, C. B. 1986. Genetic basis of cold adaptation in laboratory and wild mice, Mus domesticus. Pages 497-504 in H. C. Heller, X. J. Musacchia, and L. C. H. Wang, eds. Living in the cold: physiological and biochemical adaptations. Elsevier, New York.

1992. Clinal variation in cold adaptation in Mus domesticus: verification of predictions from laboratory populations. Am. Nat. 139:1219-1236.

- 1994. Evolutionary inferences from genetic analyses of cold adaptation in laboratory and wild populations of the house mouse, Mus domesticus. Pages 278304 in C. R. B. BOAKE, ed. Quantitative genetic studies of behavioral evolution. University of Chicago Press, Chicago.

LyNCH, G. R. 1973. Seasonal changes in thermogenesis, organ weights, and body composition in the white-footed mouse, Peromyscus leucopus. Oecologia 13:363376.

LYNCH, G. R., C. B. LYNCh, M. DuBe, and C. Allen. 1976. Early cold exposure: effects of behavioral and physiological thermoregulation in the house mouse, Mus musculus. Physiol. Zool. 49:191-199.

Lyon, M. F., and A. G. Searle. 1989. Genetic variants and strains of the laboratory mouse. $2 \mathrm{~d}$ ed. Oxford University Press, New York. $876 \mathrm{pp}$.

MacMillen, R. E., and T. Garland, Jr. 1989. Adaptive physiology. Pages 143-168 in G. L. Kirkland, Jr., and J. N. LaYne, eds. Advances in the study of Peromyscus (Rodentia). Texas Tech University Press, Lubbock.

MaIer, H. A., and D. D. FeIsT. 1991. Thermoregulation, growth, and reproduction in Alaskan collared lemmings: role of short day and cold. Am. J. Physiol. 261:R522R530.

MAREK, P., and J. SzACKI. 1988. Environmentally induced analgesia in wild mice: comparison with laboratory mice. Physiol. Zool. 61:330-332.

Mason, E. B. 1974. Metabolic responses of two species of Peromyscus raised in different thermal environments. Physiol. Zool. 47:68-74.

MEJSNAR, J., and L. JANSKY. 1970. Shivering and nonshivering thermogenesis in the bat (Myotis myotis Borkh.) during arousal and hibernation. Can. J. Physiol. Pharmacol. 48:102-106.

1971. Nonshivering thermogenesis and calorigenic action of catecholamines in the white mouse. Physiol. Bohemoslov. 20:157-162.

Merritt, J. F. 1984. Growth patterns and seasonal thermogenesis of Clethrionomys gapperi inhabiting the Appalachian and Rocky mountains of North America. Pages 201-213 in J. F. MERritT, ed. Winter ecology of small mammals. Carnegie Museum of Natural History, Pittsburgh.

1986. Winter survival adaptations of the short-tailed shrew (Blarina brevicauda) in an Appalachian montane forest. J. Mammal. 67:450-464.

Millar, J. S., and D. A. L. Threadgill. 1987. The effect of captivity on reproduction and development in Peromyscus maniculatus. Can. J. Zool. 65:1713-1719. 
Norusis, M. J. 1992. SPSS/PC+ advanced statistics version 5.0. SPSS, Chicago. 481 pp.

Plomin, R. J., J. C. DeFries, and G. E. McClearn. 1990. Behavioral genetics: a primer. 2 d ed. W. H. Freeman, New York. 455 pp.

Plomin, R. J., and M. Manosevitz. 1974. Behavioral polytypism in wild Mus musculus. Behav. Genet. 4:145-157.

PRICE, E. O. 1984. Behavioral aspects of animal domestication. Q. Rev. Biol. 59:132.

Riska, B., W. R. Atchley, and J. J. Rutledge. 1984. A genetic analysis of targeted growth in mice. Genetics 107:79-101.

Robeson, B. L., E. J. Eisen, and J. M. Leatherwood. 1981. Adipose cellularity, serum glucose, insulin and cholesterol in polygenic obese mice fed high-fat or highcarbohydrate diets. Growth 45:198-215.

RosenmanN, M., and P. R. MORRISON. 1974. Maximum oxygen consumption and heat loss facilitation in small homeotherms by He- $\mathrm{O}_{2}$. Am. J. Physiol. 226:490-495.

SAGE, R. D. 1981. Wild mice. Pages 39-90 in H. L. Foster, J. D. Small, and J. G. Fox, eds. The mouse in biomedical research. Vol. 1. History, genetics, and wild mice. Academic Press, New York.

SCHECK, S. H. 1982a. A comparison of thermoregulation and evaporative water loss in the hispid cotton rat, Sigmodon bispidus texianus, from northern Kansas and south-central Texas. Ecology 63:361-369.

- $1982 b$. Development of thermoregulatory abilities in the neonatal hispid cotton rat, Sigmodon hispidus texianus, from northern Kansas and south-central Texas. Physiol. Zool. 55:91-104.

Selander, R. K. 1970. Behavior and genetic variation in natural populations. Am. Zool. 10:53-66.

Stinker, B. K., and S. A. Glantz. 1985. Multiple regression for physiological data analysis: the problem of multicollinearity. Am. J. Physiol. 249:R1-R12.

SMITH, R. H. 1972. Wildness and domestication in Mus musculus: a behavioral analysis. J. Comp. Physiol. Psychol. 79:22-29.

- 1978. Selection for shuttle avoidance in wild Mus musculus. Behav. Genet. $8: 269-374$.

- 1985. Behavioral measures of drift in Mus musculus. Behav. Genet. 15:483497.

SPARTI, A. 1992. Thermogenic capacity of shrews (Mammalia, Soricidae) and its relationship with basal rate of metabolism. Physiol. Zool. 65:77-96.

Thornhill, J., and I. Halvorson. 1992. Differences in brown adipose tissue thermogenic responses between Long-Evans and Sprague-Dawley rats. Am. J. Physiol. 263:R59-R69.

Tomasi, T. E., and A. S. Gleit. 1992. The allometry of thyroxine utilization rates. Pages 64-82 in T. E. TOMAsi and T. H. HorTon, eds. Mammalian energetics. Cornell University Press, Ithaca, N.Y.

Toması, T. E., and T. H. Horton. 1992. Mammalian energetics. Cornell University Press, Ithaca, N.Y. $276 \mathrm{pp}$.

Trayhurn, P., and D. G. Nicholls. 1986. Brown adipose tissue. Arnold, London. 374 pp. 
Tucker, P. K., B. K. Lee, B. L. Lundrigan, and E. M. Eicher. 1992. Geographic origin of the Y chromosomes in "old" inbred strains of mice. Mamm. Genome 3:254261.

Webster, A. J. F. 1974. Adaptation to cold. Pages 71-106 in D. Robertshaw, ed. Environmental physiology. University Park Press, Baltimore.

Withers, P. C. 1977. Measurement of $\dot{\mathrm{V}}_{2}, \dot{\mathrm{V}} \mathrm{CO}_{2}$, and evaporative water loss with a flow-through mask. J. Appl. Physiol. 42:120-123.

Withers, K. W., and A. J. HulBert. 1988. Cold acclimation in the marsupial Antechinus stuartii: thyroid function and metabolic rate. Aust. J. Zool. 36:421-427.

Wunder, B. A. 1981. Effects of short-term, daily, cold exposure on brown adipose tissue and non-shivering thermogenesis in the house mouse and prairie vole. Acta Univ. Carol. 1979:315-318.

- 1984. Strategies for, and environmental cueing mechanisms of, seasonal changes in thermoregulatory parameters of small mammals. Pages 165-172 in J. F. MerritT, ed. Winter ecology of small mammals. Carnegie Museum of Natural History, Pittsburgh.

-1992. Morphophysiological indicators of the energy state of small mammals. Pages $83-104$ in T. E. Tomasi and T. H. HorTon, eds. Mammalian energetics. Cornell University Press, Ithaca, N.Y.

YouseF, M. K., and H. D. JoHnson. 1975. Thyroid activity in desert rodents: a mechanism for lowered metabolic rate. Am. J. Physiol. 229:427-431.

Zegers, D. A., and J. F. Merritt. 1988. Adaptations of Peromyscus for winter survival in an Appalachian montane forest. J. Mammal. 69:516-523. 